\title{
Nitrate leaching from short-hydroperiod floodplain soils
}

\author{
B. Huber ${ }^{1,2}$, J. Luster ${ }^{1}$, S. M. Bernasconi ${ }^{2}$, J. Shrestha ${ }^{1}$, and E. Graf Pannatier ${ }^{1}$ \\ ${ }^{1}$ Swiss Federal Institute for Forest, Snow, and Landscape Research, Zuercherstrasse 111, 8903 Birmensdorf, Switzerland \\ ${ }^{2}$ Geological Institute, ETH Zurich, Sonneggstrasse 5, 8092 Zurich, Switzerland \\ Correspondence to: E. Graf Pannatier (elisabeth.pannatier@wsl.ch)
}

Received: 9 December 2011 - Published in Biogeosciences Discuss.: 14 May 2012

Revised: 12 October 2012 - Accepted: 15 October 2012 - Published: 9 November 2012

\begin{abstract}
Numerous studies have shown the importance of riparian zones to reduce nitrate $\left(\mathrm{NO}_{3}^{-}\right)$contamination coming from adjacent agricultural land. Much less is known about nitrogen $(\mathrm{N})$ transformations and nitrate fluxes in riparian soils with short hydroperiods ( $1-3$ days of inundation) and there is no study that could show whether these soils are a N sink or source.

Within a restored section of the Thur River in NE Switzerland, we measured nitrate concentrations in soil solutions as an indicator of the net nitrate production. Samples were collected along a quasi-successional gradient from frequently inundated gravel bars to an alluvial forest, at three different depths $(10,50$ and $100 \mathrm{~cm})$ over a one-year period. Along this gradient we quantified $\mathrm{N}$ input (atmospheric deposition and sedimentation) and $\mathrm{N}$ output (leaching) to create a nitrogen balance and assess the risk of nitrate leaching from the unsaturated soil to the groundwater.

Overall, the main factor explaining the differences in nitrate concentrations was the field capacity (FC). In subsoils with high FCs and VWC near FC, high nitrate concentrations were observed, often exceeding the Swiss and EU groundwater quality criterions of 400 and $800 \mu \mathrm{moll}^{-1}$, respectively. High sedimentation rates of river-derived nitrogen led to apparent $\mathrm{N}$ retention up to $200 \mathrm{~kg} \mathrm{~N} \mathrm{ha}^{-1} \mathrm{yr}^{-1}$ in the frequently inundated zones. By contrast, in the mature alluvial forest, nitrate leaching exceeded total $\mathrm{N}$ input most of the time. As a result of the large soil $\mathrm{N}$ pools, high amounts of nitrate were produced by nitrification and up to $94 \mathrm{~kg} \mathrm{~N}-\mathrm{NO}_{3}^{-} \mathrm{ha}^{-1} \mathrm{yr}^{-1}$ were leached into the groundwater. Thus, during flooding when water fluxes are high, nitrate from soils can contribute up to $11 \%$ to the total nitrate load in groundwater.
\end{abstract}

\section{Introduction}

Intensive agriculture, high population densities and high atmospheric nitrogen input have led to nitrate $\left(\mathrm{NO}_{3}^{-}\right)$contamination of surface and groundwater in many regions of the world. Besides eutrophication, which can lead to an accelerated loss of biological diversity (Vitousek et al., 1997), there are serious concerns whether elevated nitrate concentrations in drinking water pose a health risk to humans by causing illnesses such as infantile methaemoglobinaemia or cancer of the digestive tract (Powlson et al., 2008).

The importance of riparian zones in reducing nitrate inputs from adjacent agriculture land into streams and groundwater has been shown (Hefting et al., 2006; Mayer et al., 2007). However, most of these studies were performed in floodplains with long hydroperiods (week to months of inundation) or permanently inundated water bodies with strongly reducing conditions, facilitating nitrate removal by denitrification. Much less is known about $\mathrm{N}$ processes in riparian soils with short hydroperiods (1-3 days of inundation) (Noe and Hupp, 2007). In such soils, drying and re-wetting may increase the microbial activity and thereby increase the decomposition of soil organic matter that has been accumulated in the past by sedimentation (Howard-Williams, 1985; Samaritani et al., 2011). This leads to high substrate availability for nitrification during non-flooded periods (Baldwin and Mitchell, 2000; Olde Venterink et al., 2006). In addition, inundation times might be too short to establish strong reducing conditions necessary for denitrification (Noe and Hupp, 2007).

There are a number of studies focusing on denitrification as a means of permanent $\mathrm{N}$ removal from floodplain soils and sediments, but there are only a few considering other processes within the $\mathrm{N}$ cycle, in particular nitrification during 
unsaturated conditions (Pinay et al., 1995; Hefting et al., 2004). However, none of these studies could show whether the unsaturated zone of a floodplain soil is a $\mathrm{N}$ sink or source.

In this study, we monitored nitrate concentrations in soil solutions as an indicator of the net nitrate production. To the best of our knowledge, there are no comparable studies. The study was performed within a restored section of the Thur River corridor (Canton Thurgau, NE Switzerland) and was part of the interdisciplinary project RECORD of the Competence Center Environment and Sustainability (CCES) of the ETH domain (http://www.cces.ethz.ch/projects/nature/ Record). Main objectives were (1) to explain the spatial variability of nitrate concentrations in soil solutions and relate them to soil properties and soil environmental conditions (2) to quantify nitrate leaching from the floodplain soils to the groundwater and assess the $\mathrm{N}$ saturation status of the soils (3) to create a nitrogen balance for different parts of the floodplain. Therefore, in addition to monitoring nitrate concentrations in soil solutions, we measured both the atmospheric deposition and sediment input of nitrogen and calculated the water flow for the estimation of nitrate leaching.

\section{Materials and methods}

\subsection{Test site}

The test site is located in a restored section of the Thur River near Niederneunforn (Canton Thurgau, Switzerland, $8^{\circ} 77^{\prime} 12^{\prime \prime} \mathrm{E} ; 47^{\circ} 59^{\prime} 10^{\prime \prime} \mathrm{N}$ ). The river originates in the limestone formation of the Mount Säntis region (2500 ma.s.l.) and drains a catchment area of $1750 \mathrm{~km}^{2}$ before entering the Rhine river at $345 \mathrm{~m}$ a.s.l. Because there are no reservoirs or natural lakes, the river discharge is dominated by a flashy flow regime with extremes of 2 and $1130 \mathrm{~m}^{3} \mathrm{~s}^{-1}$ and an average of $50 \mathrm{~m}^{3} \mathrm{~s}^{-1}$ (recording period 1904-2005, FOEN, 2011). Floods are observed in spring due to snowmelt, and in summer and fall during heavy rainfall events.

The Thur River was channelized in the 1890 s to protect adjacent lands against flooding. Starting in 1993, several 1-3 km long river sections were restored, among them the $2 \mathrm{~km}$ long stretch at the test site. During restoration the river was widened and levees were lowered to increase the hydrological connectivity between the main channel and an alluvial forest. Following the restoration, a dynamic quasisuccessional gradient including dynamic gravel bars and more stable alluvial forests has developed and habitat diversity has increased (Peter, 2011; Samaritani et al., 2011).

The study was carried out in three functional process zones (FPZ), i.e. hydrogeomorphic patches which were identified based on vegetation, distance to the river and topography (Thorp et al., 2006; Samaritani et al., 2011): (1) gravel bar next to the river covered by up to $1 \mathrm{~m}$ of fine sediments and densely overgrown by the dominant grass Phalaris arundinacea (GRASS); (2) riverbanks composed of older sediments

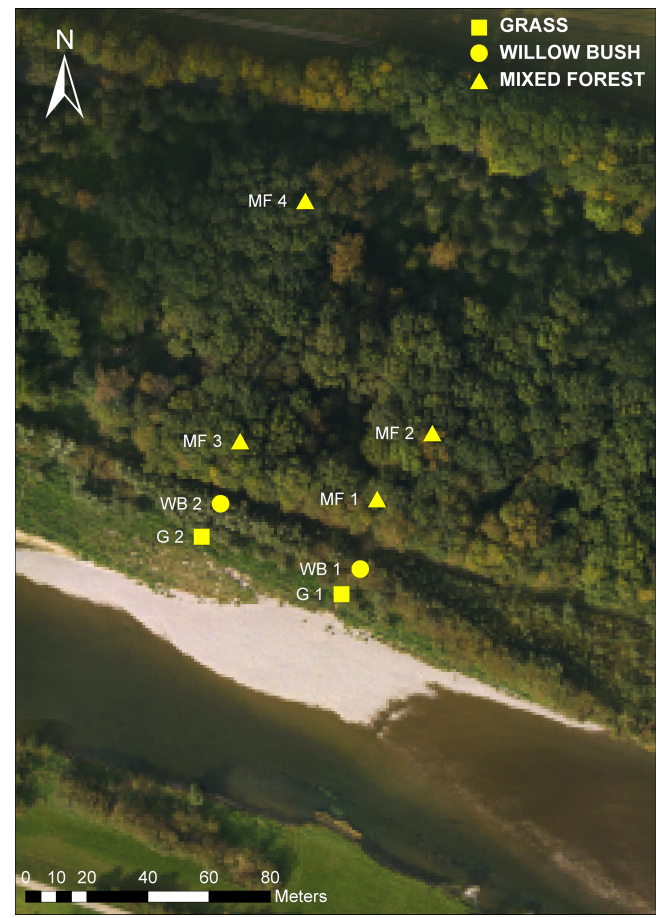

Fig. 1. Aerial view of the Thur River test site near Niederneunforn (NE Switzerland) showing the different plots in the three functional process zones.

and dominant vegetation of Salix viminalis that was planted as part of the restoration in order to stabilize the new banks (WILLOW BUSH); and (3) old riparian forest located 50$90 \mathrm{~m}$ from the edge of the river dominated by Acer pseudoplatanus and Fraxinus excelsior trees (MIXED FOREST). No nitrogen fixing plants have been found in any of these FPZs; GRASS and WILLOW BUSH are considered as "dynamic" and MIXED FOREST as "stable" FPZs (Samaritani et al., 2011). For this study, two parallel transects across the described FPZs were selected, consisting of 8 plots in total (Fig. 1). Soil thickness increased along both transects from GRASS to MIXED FOREST (Table 1) and soil properties (texture, total organic carbon, total nitrogen) between 0 $1 \mathrm{~m}$ depth exhibited a larger horizontal than vertical variability (Samaritani et al., 2011). Due to differences in altitude, sampling plots within these FPZs are exposed to different flooding frequencies and durations (Table 1, Fig. 2). Major flooding during the observation period occurred on 16 June $\left(335 \mathrm{~m}^{3} \mathrm{~s}^{-1}\right), 18$ July $\left(748 \mathrm{~m}^{3} \mathrm{~s}^{-1}\right), 8$ and 30 December 2009 (338 and $362 \mathrm{~m}^{3} \mathrm{~s}^{-1}$ ).

At the test site the Thur River infiltrates year-round into the groundwater (Vogt et al., 2010a). Below GRASS and WILLOW BUSH the groundwater is mainly the freshly infiltrated river water with 1 to 5 days travel time, whereas travel times from the river to the MIXED FOREST are in the order of weeks (Peter, 2011). 
Table 1. Hydrogeological characteristics and soil properties of sampling plots within different FPZs. Soil properties are given for the top $10 \mathrm{~cm}$ of soil.

\begin{tabular}{ll|rr|rr|rrrr}
\hline & Units & \multicolumn{2}{|c|}{ GRASS } & \multicolumn{2}{|c|}{ WILLOW BUSH } & \multicolumn{4}{c}{ MIXED FOREST } \\
\hline & & G1 & G2 & WB1 & WB2 & MF1 & MF2 & MF3 & MF4 \\
\hline Elevation $^{1}$ & ma.s.1. & 372.9 & 373.2 & 373.4 & 373.4 & 374.1 & 373.9 & 374.0 & 373.0 \\
GW level below surface $^{2}$ & $\mathrm{~m}$ & -1.1 & -1.1 & -1.5 & -1.5 & -2.2 & -1.8 & -2.1 & -1.2 \\
Flooding frequency $^{3}$ & times yr $^{-1}$ & 15 & 8 & 7 & 7 & 1 & 1 & 1 & 1 \\
Flooding duration $^{3}$ & days & $1-3$ & 1 & 1 & 1 & $<1$ & $<1$ & $<1$ & $<1$ \\
Soil thickness & $\mathrm{m}$ & $0.5-1.3$ & $0-0.5$ & $1.0-2.2$ & $\mathrm{ND}$ & 2.8 & 1.5 & $\mathrm{ND}$ & 2.4 \\
Sand & $\mathrm{g} \mathrm{kg}^{-1}$ & 497 & 755 & 322 & 461 & 304 & 312 & 369 & 227 \\
Clay & $\mathrm{g} \mathrm{kg}^{-1}$ & 114 & 54 & 138 & 112 & 170 & 167 & 144 & 194 \\
Total N & $\mathrm{g} \mathrm{kg}^{-1}$ & 1.21 & 0.81 & 1.46 & 1.05 & 1.97 & 1.12 & 1.33 & 1.60 \\
C/N ratio & $\mathrm{g} \mathrm{g}^{-1}$ & 14.6 & 15.7 & 14.3 & 16.0 & 13.5 & 14.3 & 13.9 & 14.4 \\
\hline
\end{tabular}

\footnotetext{
1 Measured in May 2010.

2 Average GW level during the observation period (28 March 2009-29 March 2010).

${ }^{3}$ Flood duration per event, approximated using the river discharge data for the period of 28 March 2009-29 March 2010 and inundation maps produced by digital terrain modelling based on river cross section measurements (Pasquale et al., 2011).

${ }^{4}$ Corresponds to the fine-textured material overlying the coarse gravel. The soil depth (limit between fine-textured material and coarse gravel) was determined by visual inspection of the drilling cores collected during the installation of 29 piezometers from the gravel bar to the alluvial forest (transect B in Schneider et al., 2011). No piezometers were installed in WB2 and MF3.

$\mathrm{ND}=$ not determined.
}

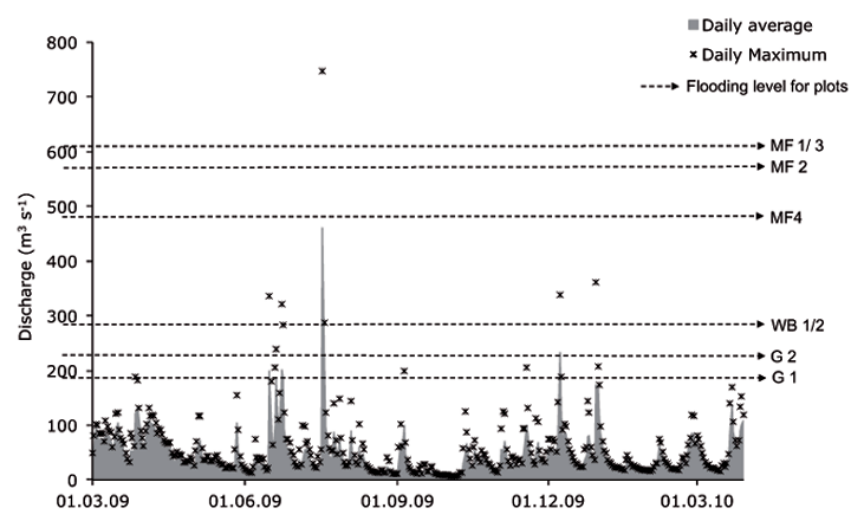

Fig. 2. Daily average and maximum discharge of the Thur River at the test site, and minimum discharge required for inundation of the different plots (Pasquale et al., 2011).

\subsection{Soil sampling and soil properties}

Topsoil cores $(6.5 \mathrm{~cm}$ diameter, $0-10 \mathrm{~cm}$ deep) were collected in April 2008 at all 8 plots (Fig. 1, Table 1), close to the lysimeters used to collect soil solution. Longer cores were not collected to avoid any disturbance around the installed instruments and because the soil properties did not vary much with depth (Samaritani et al., 2011). In each plot, three soil cores were collected and pooled. Soils were dried $\left(40^{\circ} \mathrm{C}\right.$, $48 \mathrm{~h}$ ) and then sieved at $2 \mathrm{~mm}$ mesh size. Soil texture of dried samples was measured using the pipette method (Gee and Bauder, 1986) after removing organic matter with hydrogen peroxide and dispersing with sodium hexametaphosphate. Grain size classes were defined as clay $(<2 \mu \mathrm{m})$, silt $(2-63 \mu \mathrm{m})$ and sand $(63 \mu \mathrm{m}-2 \mathrm{~mm})$. Soil $\mathrm{pH}$ was measured in a $1: 2$ slurry of dried soil in $0.01 \mathrm{M}$ calcium chloride after 30 min equilibration. Total $\mathrm{N}$ and organic and inorganic $\mathrm{C}$ contents of finely ground, dried soils were determined as described by Walthert et al. (2010).

\subsection{Atmospheric $\mathbf{N}$ deposition}

Precipitation samples were collected every two weeks from April 2009 to September 2009 and then monthly till March 2010 using the throughfall method (Thimonier, 1998; Thimonier et al., 2005). In the MIXED FOREST, ten funneltype $\left(100 \mathrm{~cm}^{2}\right.$ opening) polyethylene collectors (throughfall) were randomly distributed along MF1, MF2 and MF4, and three collectors (bulk precipitation) in the open area close to the forest stand.

In the laboratory, samples were pooled, filtered $(0.45 \mu \mathrm{m})$ and analyzed for $\mathrm{pH}$, electrical conductivity (EC), dissolved organic carbon (DOC), total $\mathrm{N}(\mathrm{TN})$, and major cations and anions. The $\mathrm{pH}$ was measured potentiometrically by means of a combined glass electrode (Radiometer analytical, pHC4000-8), EC conductometrically (Radiometer analytical, CDC 241-9). Total cation concentrations were analyzed by ICP-AES (ARL 3580, Perkin-Elmer OPTIMA3000) and the concentrations of major anions were analyzed by ion chromatography (DX-120, Dionex). Ammonium $\left(\mathrm{NH}_{4}^{+}\right)$was determined colorimetrically (indophenol blue) through automated flow injection analysis and DOC/TN by hightemperature combustion followed by infrared detection of $\mathrm{CO}_{2}$ and by chemoluminescence detection of the reaction product of NO with ozone, respectively (Shimadzu TOC-V and Skalar Formacs TOC/TN analyzer). The concentration of dissolved organic $\mathrm{N}$ (DON) was calculated as difference between $\mathrm{TN}$ and the sum of ammonium, nitrite and nitrate. 
Precipitation amounts for missing intervals were estimated using regressions of precipitation amounts measured by our collectors against precipitation data of the nearby RECORD meteorological station (Pasquale et al., 2011), and missing element concentrations were estimated using linear regression between concentrations and precipitation volumes (Thimonier et al., 2005). Bulk and throughfall deposition fluxes were calculated by multiplying the 14-days or monthly precipitation amounts with concentrations. In GRASS, the atmospheric $\mathrm{N}$ deposition is equal to $\mathrm{N}$ fluxes in bulk deposition. In the MIXED FOREST, estimates of dry deposition were derived from the difference between throughfall and bulk precipitation, with correction for canopy exchange processes (Thimonier et al., 2005). We used the canopy budget model developed by Ulrich (1983) and synthesized by De Vries et al. (2001). In this model, atmospheric $\mathrm{N}$ deposition represents throughfall $\mathrm{N}$ fluxes plus or minus canopy exchanges (uptake or leaching). It is assumed that sodium does not interact with the canopy and therefore can be used as a tracer for estimating the dry deposition of base cations. The model also includes the relative exchange capacities of protons, ammonium, and nitrate (Thimonier et al., 2005). In WILLOW BUSH, no collectors were installed and we assumed the atmospheric $\mathrm{N}$ deposition to be equal to the one in the MIXED FOREST.

\subsection{N sedimentation}

Determination of $\mathrm{N}$ sedimentation was performed during the period from April 2010 to March 2011. In GRASS and WILLOW BUSH where sedimentation was high, $\mathrm{N}$ sedimentation was determined using erosion pins (Steiger et al., 2003). In each plot, nine pins with a distance of $5 \mathrm{~m}$ to each other were piled $0.5 \mathrm{~m}$ into the ground forming a $3 \times 3$ square. The changes in the exposed length and the bulk density of the sediments were used to calculate the deposited amount. Fresh sediments were collected, dried and analyzed for total $\mathrm{N}$.

In MIXED FOREST, where the sedimentation was lower, three artificial turf mats $(0.3 \times 0.45 \mathrm{~m})$ with $2 \mathrm{~cm}$ plastic tufts were installed at each plot before floodings predicted by discharge forecasting (Steiger et al., 2003; FOEN, 2011). After flooding, sediment traps were removed and sediments were washed out using deionized water and collected in plastic bins. On the next day, the settled sediments were dried, weighed and analyzed for total $\mathrm{N}$.

\subsection{Soil solution, river water sampling}

Soil solution, river water and water from the side channel were sampled every two weeks from April 2009 till July 2009 and then monthly till March 2010. Additional samplings were carried out during and after the flood events of 16 June 2009 (one and ten days later) and 18 July 2009 (one, two, four and nine days later). Soil solution was collected at 3 replicate locations (parallel to the river flow di- rection and $5.5 \mathrm{~m}$ apart) and two depths $(10,50 \mathrm{~cm})$ at each plot in GRASS and WILLOW BUSH and at 3 depths (10, $50,100 \mathrm{~cm})$ at each plot in the MIXED FOREST. Tension lysimeters (highflow porous ceramic cups, Soilmoisture Equipment Corp., Santa Barbara, CA, USA) were installed at least six weeks and flushed five times before the first sampling. Two to three days before each sampling, a constant vacuum of $500-600 \mathrm{hPa}$ was applied to the suction cups. Collection volumes were measured in the field before aliquots were taken to the laboratory. Upon arrival in the laboratory, the 3 replicates of each plot and depth were pooled proportionally to the sampling volume. Pooled samples were handled together with the precipitation samples and analyzed for the same constituents.

\subsection{Soil environmental conditions}

Soil temperature $(T)$ and volumetric water content (VWC) were recorded in half-hour intervals at all plots and depths using Decagon sensors (EC-TM, EC-5, 5TE) and data loggers (Em50R, Decagon Devices Inc., Pullman, WA, USA). Soil moisture sensors were installed from the soil surface by (i) drilling a hole in a $60^{\circ}$ angle, (ii) placing the sensor at the bottom of the hole, and (iii) re-filling the hole. We used custom-made tools to ensure placement of the sensor tongs at an unaltered bulk density. Each EC-TM and EC-5 sensor was calibrated individually in the laboratory, reproducing the same bulk density as the one in the field. Dry bulk density was determined in each FPZ at two depths (5$15 \mathrm{~cm}$ and $45-55 \mathrm{~cm})$ in soil pits close to the sensors using metallic cylinders of known volume $\left(1000 \mathrm{~cm}^{3}\right)$. For the 5TE sensors the calibration for mineral soils provided by the manufacturer was used. For plots in GRASS, WILLOW BUSH as well as MF1 and MF3, one EC-TM sensor (recording $T$ and VWC) and two EC-5 (VWC only) sensors were installed at each depth (close to the replicate locations of the soil solution samplers). For MF2 and MF4, 5TE sensors were installed at 10 and $50 \mathrm{~cm}$ depth at two replicate locations and at one location also at $100 \mathrm{~cm}$. Recording period was 28 March 2009-29 March 2010, except for MF1 at $100 \mathrm{~cm}$ depth (30 August 2009-29 March 2010) and MF3 at all depths (25 July 2009-29 March 2010). For the data evaluation, means of VWC replicates were taken for the same periods when soil solutions were collected (average of halfhourly measurements over 2-3 days).

The soil matric potential $(\Psi)$ was measured with tensiometers built of ceramic cups (highflow porous ceramic cups, Soilmoisture Equipment Corp., Santa Barbara, CA, USA) between saturation and $-900 \mathrm{hPa}$ and with MPS1 Decagon sensors between $-100 \mathrm{hPa}$ to $-5000 \mathrm{hPa}$ for each plot and depth. The measurements of VWC and $\Psi$ were used to validate the soil water retention curve used for the modelling of the water fluxes. Field capacity (FC) was defined as the VWC for $\Psi$ between $-100 \mathrm{hPa}$ and $-60 \mathrm{hPa}$ based on the manual readings of the tensiometers. 


\subsection{Modelling of water and $\mathbf{N}$ fluxes}

The CoupModel was used to simulate daily water fluxes for all plots. Except for WILLOW BUSH, only one simulation was made for both replicate plots. This model is based on coupled heat and mass transfer and was developed for soil-plant-atmosphere systems (Jansson and Karlberg, 2004). Meteorological data (air temperature, precipitation, relative humidity, global radiation, wind speed) and continuously recorded groundwater levels were received from the meteorological station (Pasquale et al., 2011) and pressure head sensors installed in observation wells, respectively (Schneider et al., 2011).

Water retention curves were calculated for each plot using van Genuchten parameters determined for different classes of bulk density and texture (Teepe et al., 2003) and were validated by the measured VWC and $\Psi$. The saturated hydraulic conductivity (Ksat) was derived from pedotransfer functions based on soil texture, bulk density and soil organic matter content (Teepe et al., 2003; KA5, 2005). The model was calibrated and validated with the measured VWC. The results from the model were compared to the measurements using the root mean square error (RMSE) and the mean error (ME). Output data were daily soil water fluxes at $50 \mathrm{~cm}$ below the surface in GRASS and WILLOW BUSH and at $100 \mathrm{~cm}$ in MIXED FOREST. Annual N fluxes were calculated by summing up seasonal $\mathrm{N}$ fluxes, which were calculated by multiplying three-month averages (March-May, June-August, September-November, December-February) of $\mathrm{NO}_{3}^{-}, \mathrm{NH}_{4}^{+}$, and DON concentrations in soil solutions and the corresponding three-monthly water fluxes. $\mathrm{N}$ fluxes during flooding were based on average $\mathrm{N}$ concentrations and water fluxes during these events. The standard error of $\mathrm{N}$ fluxes was calculated using the standard error of $\mathrm{N}$ concentrations during the period considered.

\subsection{Statistical analyses}

Data were analyzed using linear mixed effect models fitted by maximum likelihood (lme function from the nlmepackage of R 2.11.1, R Development Core Team, 2010). The models included the nested random effects FPZ, plot, and depth while soil environmental conditions ( $T$, VWC, FC) and sampling date (time) were the fixed effects tested. Effects of soil environmental conditions and sampling date on nitrate concentrations in soil solutions were tested. The shape of the data distribution was visualized with histograms and probability plots. The nitrate data were log transformed to improve their distribution. Significance level was $p<0.05$. Boxplots for nitrate concentrations and VWCs were drawn using the statistic program SPSS 17 (SPSS Inc.).

\section{Results}

\subsection{Precipitation and soil temperature}

Total precipitation from 28 March 2009 to 29 March 2010 was $910 \mathrm{~mm}$. The lowest monthly amount was measured in April $(12 \mathrm{~mm})$ and the highest in July $(140 \mathrm{~mm})$, with a daily peak of $36 \mathrm{~mm}$ on 17 July 2009 (Fig. 3).

The soil temperature at $50 \mathrm{~cm}$ did not differ much between GRASS and WILLOW BUSH ( std error $= \pm 1^{\circ} \mathrm{C}$ ). The daily average exhibited a maximum of $21^{\circ} \mathrm{C}$ in August 2009 and a minimum of $2{ }^{\circ} \mathrm{C}$ in February 2010. In MIXED FOREST, the daily average temperature at $100 \mathrm{~cm}$ depth was maximum in August $\left(17^{\circ} \mathrm{C}\right)$ and minimum in February $\left(4^{\circ} \mathrm{C}\right.$; Fig. 3$)$

\subsection{Soil properties}

Soils became more finely textured and total nitrogen (TN) increased from GRASS to MIXED FOREST (Table 1). The dry bulk density in GRASS was 0.8 in the topsoil $(5-15 \mathrm{~cm})$ and 1.1 in the subsoil $(45-55 \mathrm{~cm})$. The respective bulk densities in WILLOW BUSH and MIXED FOREST were higher, i.e. about 1.1 in the topsoil and 1.3 in the subsoil (data not shown). The $\mathrm{C} / \mathrm{N}$ ratio was around 15 in all FPZs. The soils in all FPZs are haplic Fluvisols (calcaric, humic) according to the world reference base for soil resources (IUSS Working Group WRB, 2006).

\subsection{Hydrochemistry}

The mean chemical composition of the water samples (river, side channel, bulk deposition and soil solution) is presented in Table 2. Only the soil solution data from the lower soil compartment (i.e. $50 \mathrm{~cm}$ in GRASS and WILLOW BUSH and $100 \mathrm{~cm}$ in MIXED FOREST) are shown. The $\mathrm{pH}$ values of the soil solutions, river water and water from the side channel were between 8.2 and 9.6. EC values in soil solutions showed a large variability ranging from $598 \mu \mathrm{S} \mathrm{cm}^{-1}$ to $1006 \mu \mathrm{S} \mathrm{cm}^{-1}$. By contrast, the $\mathrm{EC}$ in the river water $\left(402 \mu \mathrm{S} \mathrm{cm}^{-1}\right)$ and side channel $\left(478 \mu \mathrm{S} \mathrm{cm}^{-1}\right)$ were distinctly lower. Highest nitrate concentrations were measured at MF4 $\left(1153 \mu \mathrm{moll}^{-1}\right)$ and G1 $\left(903 \mu \mathrm{moll}{ }^{-1}\right)$, whereas concentrations at WB1, WB2 (both $<44 \mu \mathrm{moll}^{-1}$ ) and MF3 $\left(93 \mu \mathrm{mol}^{-1}\right)$ were lower. Nitrate concentrations in the river and side channel were similar, with 122 and $138 \mu \mathrm{moll}^{-1}$, respectively. In all samples nitrite concentrations were below $1.2 \mu \mathrm{mol}^{-1}$. In soil solutions, ammonium concentrations never exceeded $2.9 \mu \mathrm{mol}^{-1}$

\subsection{Spatial variability of nitrate concentrations, VWC and FC}

The highest nitrate concentrations were measured in GRASS at $\mathrm{G} 1$ in $10 \mathrm{~cm}$ depth and in MIXED FOREST at MF4 in $100 \mathrm{~cm}$ depth, with medians of 752 and $1149 \mu \mathrm{moll}^{-1}$, respectively (Fig. 4). Lowest nitrate concentrations were 
Table 2. Average of chemical constituents ( \pm std error) between 28 March 2009 and 29 March 2010 in soil solutions from the lowest soil compartment in different FPZs, the Thur River, side channel and bulk deposition for $n$ replicates.

\begin{tabular}{|c|c|c|c|c|c|c|c|c|c|c|c|c|}
\hline & \multirow[t]{2}{*}{ Units } & \multicolumn{2}{|c|}{$\begin{array}{l}\text { GRASS } \\
50 \mathrm{~cm}\end{array}$} & \multicolumn{2}{|c|}{$\begin{array}{l}\text { WILLOW BUSH } \\
50 \mathrm{~cm}\end{array}$} & \multicolumn{4}{|c|}{$\begin{array}{l}\text { MIXED FOREST } \\
100 \mathrm{~cm}\end{array}$} & \multirow[t]{2}{*}{$\begin{array}{r}\text { THUR } \\
\text { RIVER }\end{array}$} & \multirow[t]{2}{*}{$\begin{array}{r}\text { SIDE } \\
\text { CHANNEL }\end{array}$} & \multirow[t]{2}{*}{$\begin{array}{r}\text { BULK } \\
\text { DEPOSITION }\end{array}$} \\
\hline & & G1 & G2 & WB1 & WB2 & MF1 & MF2 & MF3 & MF4 & & & \\
\hline$n$ & & 16 & 15 & 15 & 19 & 14 & 17 & 17 & 13 & 20 & 15 & 15 \\
\hline $\mathrm{pH}$ & & $8.4 \pm 0.1$ & $8.4 \pm 0.1$ & $8.5 \pm 0.1$ & $8.2 \pm 0.1$ & $8.3 \pm 0.2$ & $9.6 \pm 0.4$ & $8.3 \pm 0.2$ & $8.8 \pm 0.4$ & $8.3 \pm 0.1$ & $8.4 \pm 0.0$ & $6.6 \pm 0.2$ \\
\hline $\mathrm{EC}$ & $\mu \mathrm{S} \mathrm{cm}^{-1}$ & $801 \pm 45$ & $709 \pm 43$ & $598 \pm 25$ & $779 \pm 40$ & $790 \pm 26$ & $855 \pm 40$ & $688 \pm 19$ & $1006 \pm 51$ & $402 \pm 23$ & $478 \pm 20$ & $18 \pm 2$ \\
\hline DOC & $\mu \mathrm{moll}^{-1}$ & $621 \pm 41$ & $895 \pm 108$ & $605 \pm 45$ & $533 \pm 70$ & $849 \pm 58$ & $743 \pm 40$ & $983 \pm 299$ & $896 \pm 82$ & $299 \pm 45$ & $207 \pm 39$ & $154 \pm 24$ \\
\hline $\mathrm{NO}_{3}^{-}$ & $\mu \mathrm{moll}^{-1}$ & $903 \pm 287$ & $283 \pm 81$ & $44 \pm 10$ & $15 \pm 7$ & $646 \pm 118$ & $589 \pm 99$ & $93 \pm 8$ & $1153 \pm 84$ & $122 \pm 11$ & $138 \pm 12$ & $35 \pm 5$ \\
\hline $\mathrm{NO}_{2}^{-}$ & $\mu \mathrm{moll}^{-1}$ & $0.4 \pm 0.1$ & $0.8 \pm 0.2$ & $<0.2$ & $<0.2$ & $<0.2$ & $0.7 \pm 0.2$ & $<0.2$ & $0.4 \pm 0.1$ & $0.8 \pm 0.1$ & $0.7 \pm 0.0$ & $1.2 \pm 0.3$ \\
\hline $\mathrm{NH}_{4}^{+}$ & $\mu \mathrm{moll}^{-1}$ & $1.6 \pm 0.4$ & $0.8 \pm 0.2$ & $2.9 \pm 1.2$ & $0.9 \pm 0.2$ & $2.1 \pm 0.8$ & $1.5 \pm 0.3$ & $1.3 \pm 0.2$ & $1.4 \pm 0.2$ & $2.0 \pm 0.5$ & $2.1 \pm 1.0$ & $45.5 \pm 7.6$ \\
\hline DON & $\mu \mathrm{moll}^{-1}$ & $162 \pm 31$ & $81 \pm 17$ & $33 \pm 3$ & $50 \pm 7$ & $134 \pm 29$ & $105 \pm 27$ & $75 \pm 7$ & $173 \pm 31$ & $34 \pm 4$ & $37 \pm 10$ & $26 \pm 6$ \\
\hline
\end{tabular}

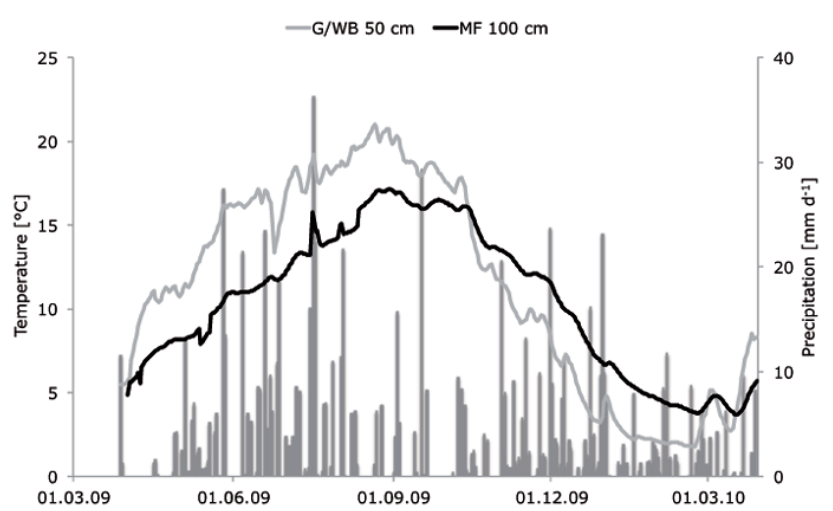

Fig. 3. Daily precipitation for the period from 28 March 200929 March 2010 and daily average soil temperature at $50 \mathrm{~cm}$ depth in GRASS and WILLOW BUSH and $100 \mathrm{~cm}$ in MIXED FOREST.

measured in WILLOW BUSH, with medians lower than $52 \mu \mathrm{moll}^{-1}$. In MIXED FOREST, nitrate concentrations generally increased with depth.

Similarly, the highest VWC medians were observed at G1 and in all plots in MIXED FOREST, and the lowest VWC were found at G2 (Fig. 4). FC was highest in MF4 (0.340.41 ) and lowest in G2 (0.09-0.14). VWC medians expressed in percentage of the FC ranged between $90 \%$ and $120 \%$ in all the plots and depths, except in G2 where VWC medians were 180-200\% FC (Fig. 4). Both nitrate concentrations and VWC were significantly correlated to $\mathrm{FC}(p \leq 0.03$ and $p<0.001$, respectively), whereas nitrate concentrations were not significantly correlated to VWC.

\subsection{Temporal variability of nitrate concentrations and VWC}

Because nitrate leaching is one of the main targets in this paper, we focus on nitrate concentrations in soil solutions and VWCs in the lowest soil horizons, i.e. $50 \mathrm{~cm}$ depth in GRASS and WILLOW BUSH, and $100 \mathrm{~cm}$ depth in MIXED FOREST.

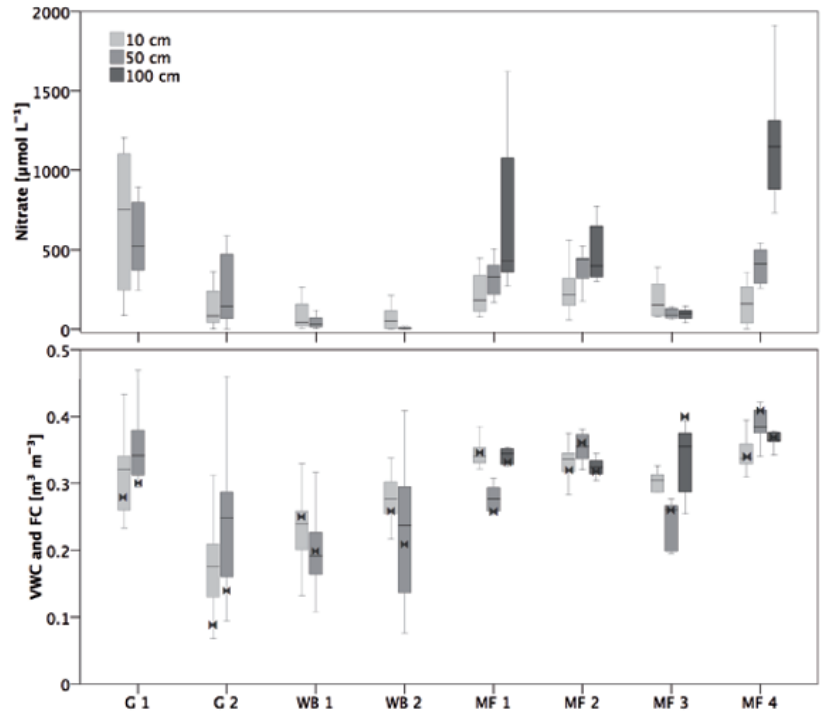

Fig. 4. (Above) Boxplot of nitrate concentrations of the pooled samples for different plots and depths showing the minimum value, lower quartile, median, upper quartile, and maximum value. Outliers ( \pm 3 standard deviation) are not shown. (Below) Boxplots of VWCs for periods when soil solutions were taken (average of halfhourly measurements over 2-3 days). Crosses indicate the field capacity (FC) for the corresponding soil layer.

In GRASS we observed the highest seasonality of nitrate concentrations. In spring (12 Mai 2009) we observed $640 \mu \mathrm{mol}^{-1}$ at G1, increasing up to $4771 \mu \mathrm{mol}^{-1}$ in late autumn (27 November 2011) and decreasing again in winter to $557 \mu \mathrm{mol}^{-1}$ (Fig. 5d). This seasonal pattern was interrupted by flooding events in June, July and December (Fig. 5a) when nitrate concentrations dropped to values close to the concentrations of the Thur River (Table 2). Both nitrate concentrations and VWC in $\mathrm{G} 2$ were distinctly lower than those in $\mathrm{G} 1$.

In WILLOW BUSH, nitrate concentrations were one order of magnitude lower than those measured in the other FPZs and the river water (Fig. 5e, Table 2). For both plots we could 

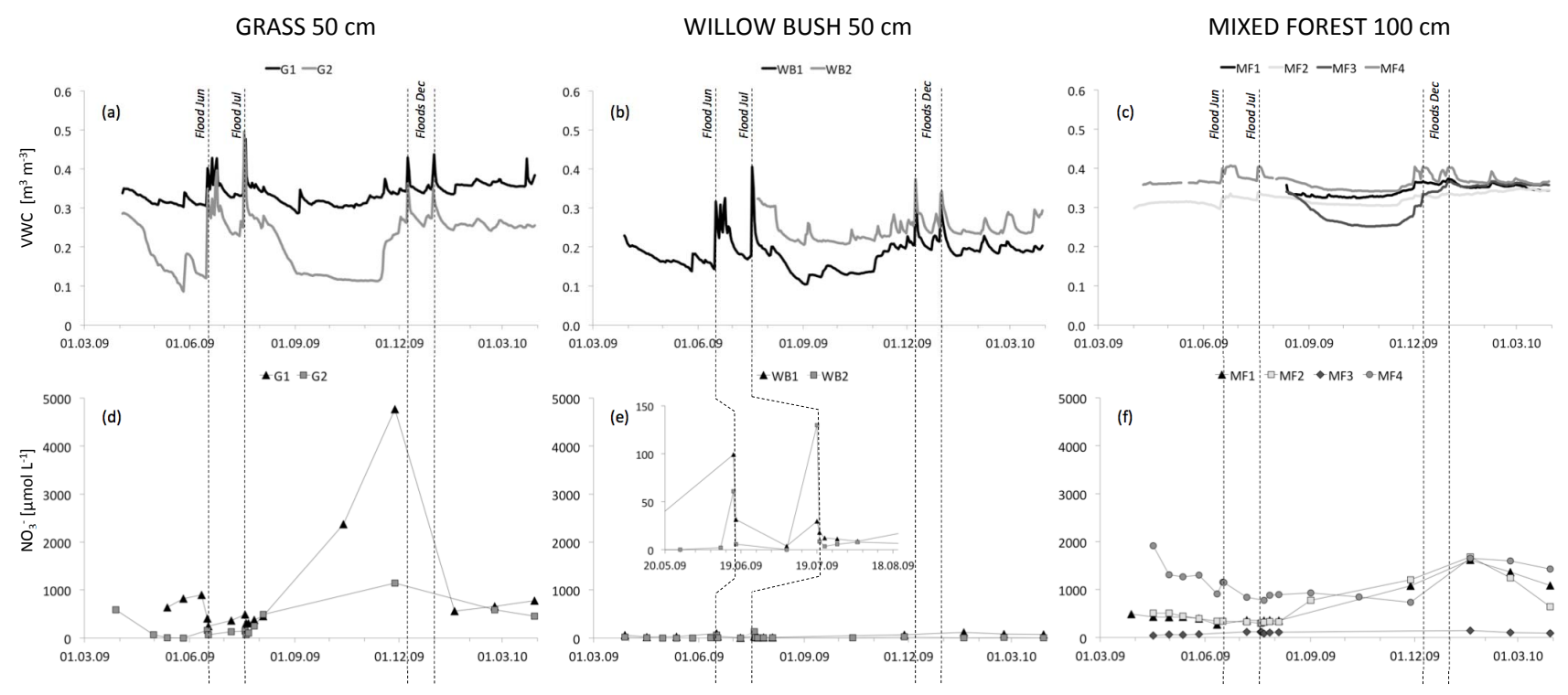

Fig. 5. VWCs (a-c) and nitrate concentrations (d-f) at $50 \mathrm{~cm}$ depth in GRASS and WILLOW BUSH and $100 \mathrm{~cm}$ in MIXED FOREST.

observe an increase in the nitrate concentrations during the flood events in summer.

MF1 and MF2 in MIXED FOREST (Fig. 5f) showed almost identical nitrate concentrations with a minimum ( 300 $\mathrm{mmol}^{-1}$ ) in summer (11 June 2009-4 August 2009) and a peak of $\sim 1600 \mu \mathrm{moll}^{-1}$ in winter (18 January 2010). In MF4 we also observed the highest nitrate concentration $\left(1654 \mu \mathrm{moll}^{-1}\right)$ in January. By contrast, nitrate concentrations in MF3 were lower with no clear seasonal pattern. In MIXED FOREST flooding did not affect nitrate concentrations strongly in any of the plots. During autumn VWC in MF3 was distinctly lower than in the other forest plots.

\subsection{Water and nitrate fluxes}

RMSE and ME of simulated VWCs in all plots equaled $15 \%$ and $10 \%$ of the mean measured VWCs, except in G2 where the performance was worse, with $41 \%$ and $33 \%$, respectively (Table 3 ). The leaching volumes at $50 \mathrm{~cm}$ depth in GRASS and WILLOW BUSH were similar, ranging from 412 to $4761 \mathrm{~m}^{-2}$ over the entire observation period. In MIXED FOREST the total water fluxes at $100 \mathrm{~cm}$ depth were highest in MF4 $\left(584 \mathrm{~m}^{-2}\right)$ and distinctly lower in the higher lying plots MF1 and MF3. In GRASS leaching volumes were similar for both summer floods, whereas in the more elevated WILLOW BUSH, leaching volumes were higher during the major flood in July. A similar picture could be observed in MIXED FOREST. In the plot with the lowest elevation (MF4), water fluxes were similar for both flood events, whereas in the other plots, leaching mainly occurred during the July flood. In all plots the largest water flows were observed during winter when compared to the other seasons (Table 3).
Leaching of nitrate over the entire observation period in MIXED FOREST and GRASS, ranged from 4 to 94 and 21 to $54 \mathrm{~kg} \mathrm{Nha}^{-1}$, respectively. By contrast, in WILLOW BUSH nitrate leaching from the soil into the groundwater did not exceed $4 \mathrm{~kg} \mathrm{~N} \mathrm{ha}^{-1}$. During flood events nitrate leaching was normally less than $5 \mathrm{~kg} \mathrm{Nha}^{-1}$, except in MF4. Similar to the pattern of water fluxes, nitrate leaching mainly occurred in winter.

\subsection{Nitrogen input}

Nitrogen inputs from the atmosphere and from sedimentation are given in Table 4. Annual atmospheric deposition in GRASS was $8 \mathrm{~kg} \mathrm{ha}^{-1}\left(5 \mathrm{~kg} \mathrm{NH}_{4}^{+}-\mathrm{Nha}^{-1}\right.$ and $3 \mathrm{~kg} \mathrm{NO}_{3}^{-}$$\mathrm{Nha}^{-1}$ ), and in MIXED FOREST and WILLOW BUSH $17 \mathrm{~kg} \mathrm{ha}^{-1}\left(14 \mathrm{~kg} \mathrm{NH}_{4}^{+}-\mathrm{N} \mathrm{ha}^{-1}, 3 \mathrm{~kg} \mathrm{NO}_{3}^{-}-\mathrm{Nha}^{-1}\right)$ mainly due to the additional canopy uptake.

The highest annual $\mathrm{N}$ sedimentation was measured in GRASS (194-252 $\mathrm{kg} \mathrm{N} \mathrm{ha}^{-1}$ ), which corresponds to an average sediment layer of approximately $2 \mathrm{~cm} \mathrm{yr}^{-1}$. In WILLOW BUSH we measured $61-86 \mathrm{~kg} \mathrm{Nha}^{-1}$ and in the MIXED FOREST $<50 \mathrm{~kg} \mathrm{Nha}^{-1}$. No sedimentation was detected in MF1 because this plot was never inundated during the observation period. Soil $\mathrm{N}$ pools of the top $10 \mathrm{~cm}$ were lowest in GRASS (700-1000 $\mathrm{kg} \mathrm{N} \mathrm{ha}^{-1}$ ) and highest in MIXED FOREST (1200-2100 kg N ha $\left.{ }^{-1}\right)$. 
Table 3. (Above) Statistical performance of the modelling of VWC, including the root mean squared error (RMSE), the mean error of estimate (ME), the average of measurements ( \pm std error) between October 2008 and May 2010 and number of measurements $(n)$. (Below) Leaching volumes and nitrate leaching for the complete sampling period (28 March 2009-29 March 2010) and during summer floods (16 June 2009 and 18 July 2009) and in winter (1 December 2009-28 February 2010). In parentheses are leaching duration in days.

\begin{tabular}{|c|c|c|c|c|c|c|c|c|}
\hline & \multicolumn{2}{|c|}{ GRASS $50 \mathrm{~cm}$} & \multicolumn{2}{|c|}{ WILLOW BUSH $50 \mathrm{~cm}$} & \multicolumn{4}{|c|}{ MIXED FOREST $100 \mathrm{~cm}$} \\
\hline & G1 & G2 & WB1 & WB2 & MF1 & MF2 & MF3 & MF4 \\
\hline \multicolumn{9}{|l|}{ Statistical performance VWC [\%] } \\
\hline RMSE & 3.4 & 8.7 & 2.5 & 2.5 & 1.7 & 2.6 & 4.5 & 2.0 \\
\hline ME & 2.8 & 7.1 & -1.2 & -1.2 & -1.0 & 1.8 & 3.1 & -1.2 \\
\hline Mean measured & 33.8 & 21.3 & 18.7 & 18.7 & 34.4 & 32.2 & 32.1 & 36.6 \\
\hline$n$ & 361 & 361 & 520 & 520 & 230 & 363 & 257 & 355 \\
\hline \multicolumn{9}{|l|}{ Leaching volume $\left[1 \mathrm{~m}^{-2}\right]$} \\
\hline 28 March 2009-29 March 2010 & $476(291)$ & $412(317)$ & $472(257)$ & $472(257)$ & $353(231)$ & 467 (234) & $288(241)$ & $584(225)$ \\
\hline Flood June & $76(6)$ & $46(15)$ & $31(14)$ & $31(14)$ & $<1(0)$ & $35(14)$ & $<1(0)$ & $116(13)$ \\
\hline Flood July & $60(3)$ & $52(7)$ & $103(6)$ & $103(6)$ & $63(5)$ & $115(4)$ & $27(4)$ & $93(5)$ \\
\hline Winter & $216(88)$ & $191(89)$ & $231(88)$ & $231(88)$ & $202(90)$ & 209 (89) & $185(90)$ & $226(87)$ \\
\hline \multicolumn{9}{|l|}{ Nitrate leaching $\left[\mathrm{kg} \mathrm{Nha}^{-1}\right]$} \\
\hline 28 March 2009-29 March 2010 & $54 \pm 12$ & $21 \pm 8$ & $4 \pm 1$ & $<1$ & $54 \pm 5$ & $59 \pm 8$ & $4 \pm 1$ & $94 \pm 18$ \\
\hline Flood June & $3 \pm 1$ & $<1$ & $<1$ & $<1$ & $<1$ & $2 \pm 1$ & $<1$ & $19 \pm 0$ \\
\hline Flood July & $3 \pm 1$ & $<1$ & $<1$ & $<1$ & $5 \pm 1$ & $5 \pm 0$ & $<1$ & $13 \pm 2$ \\
\hline Winter & $18 \pm 2$ & $12 \pm 4$ & $3 \pm 1$ & $<1$ & $42 \pm 4$ & $43 \pm 6$ & $3 \pm 1$ & $38 \pm 15$ \\
\hline
\end{tabular}

Table 4. Annual $\mathrm{N}$ fluxes ( \pm std error) $\left[\mathrm{kg} \mathrm{Nha}^{-1} \mathrm{yr}^{-1}\right]$ for the observation period from April 2009 to March 2010 and soil $\mathrm{N}$ pools $( \pm$ std error) $\left[\mathrm{kg} \mathrm{N} \mathrm{ha}^{-1}\right]$ of the top $10 \mathrm{~cm}$.

\begin{tabular}{|c|c|c|c|c|c|c|c|c|}
\hline & \multicolumn{2}{|c|}{ GRASS } & \multicolumn{2}{|c|}{ WILLOW BUSH } & \multicolumn{4}{|c|}{ MIXED FOREST } \\
\hline & G1 & $\mathrm{G} 2$ & WB1 & WB2 & MF1 & MF2 & MF3 & MF4 \\
\hline Atmposheric $\mathrm{N}$ deposition & 8 & 8 & 17 & 17 & 17 & 17 & 17 & \\
\hline $\mathrm{N}$ sedimentation ${ }^{1}$ & $252 \pm 70$ & $194 \pm 31$ & $62 \pm 26$ & $106 \pm 48$ & 0 & $23 \pm 6$ & $20 \pm 7$ & $50 \pm 4$ \\
\hline Dissolved $\mathrm{N}$ input ${ }^{2}$ & $4 \pm 2$ & $3 \pm 1$ & $4 \pm 2$ & $4 \pm 2$ & $2 \pm 1$ & $1 \pm 1$ & $8 \pm 3$ & $5 \pm 2$ \\
\hline Total $\mathrm{N}$ input & $265 \pm 71$ & $205 \pm 32$ & $83 \pm 27$ & $126 \pm 50$ & $19 \pm 1$ & $41 \pm 4$ & $45 \pm 10$ & $71 \pm 9$ \\
\hline Soil N pools $(0-10 \mathrm{~cm})$ & 1000 & 700 & 1600 & 1200 & 2100 & 1200 & 1400 & 1700 \\
\hline $\mathrm{NO}_{3}^{-}$leaching & $54 \pm 12$ & $21 \pm 8$ & $4 \pm 1$ & $<1$ & $54 \pm 5$ & $59 \pm 8$ & $4 \pm 1$ & $94 \pm 18$ \\
\hline DON leaching & $12 \pm 4$ & $6 \pm 2$ & $2 \pm 0$ & $4 \pm 1$ & $7 \pm 1$ & $12 \pm 3$ & $3 \pm 0$ & $16 \pm 4$ \\
\hline Total N leaching & $66 \pm 16$ & $27 \pm 9$ & $7 \pm 1$ & $5 \pm 1$ & $60 \pm 6$ & $71 \pm 11$ & $7 \pm 1$ & $110 \pm 23$ \\
\hline Apparent $\mathrm{N}$ retention ${ }^{3}$ & $199 \pm 88$ & $178 \pm 41$ & $76 \pm 28$ & $122 \pm 52$ & $-41 \pm 7$ & $-30 \pm 15$ & $38 \pm 10$ & $-39 \pm 32$ \\
\hline
\end{tabular}

${ }^{1} \mathrm{~N}$ sedimentation determined for the period from April 2010 to March 2011.

${ }^{2} \mathrm{~N}$ inputs in dissolved form (mainly nitrate) into the unsaturated soil from the Thur River and groundwater due to overland flooding and raising GW level.

${ }^{3}$ Denitrification not considered.

\section{Discussion}

\subsection{Soil properties}

The low $\mathrm{C} / \mathrm{N}$ ratios in all topsoils indicate favorable conditions for a high microbial activity at all depths and are characteristic of many floodplains (Tockner and Stanford, 2002; Samaritani et al., 2011). According to a study of Samaritani et al. (2011), which was performed at the same study site, the $\mathrm{C} / \mathrm{N}$ ratio does not vary with depth. In addition, they showed that our soils exhibit a high carbonate content with a $\mathrm{pH}$ of about 7.5.

When comparing the different FPZs, the finer becoming soil texture, and, as a consequence, increasing FC with in- creasing distance from the river reflect the decreasing stream energy during sediment deposition, whereas on a smaller scale the high spatial variability of the FC reflects the permanently changing geomorphic and hydrologic processes within different FPZs (Nanson and Croke, 1992; Pinay et al., 2002).

\subsection{Nitrate concentrations}

There is no literature about nitrate concentrations in soil solutions from riparian soils that would allow an appropriate comparison of our respective measurements. However, in a representative soil solution-monitoring program of $135 \mathrm{Eu}-$ ropean forest sites, only $9 \%$ exceeded the EU groundwater 
quality criterion of $800 \mu \mathrm{moll}^{-1}$ in the subsoil (De Vries et al., 2003), whereas $53 \%$ were below $100 \mu \mathrm{moll}^{-1}$. Therefore, the high nitrate concentrations in three plots of MIXED FOREST (MF1, MF2, MF4) at $100 \mathrm{~cm}$ depth and in GRASS (G1) at $50 \mathrm{~cm}$, with mean values ranging between 590 $1150 \mu \mathrm{mol}^{-1}$, fall in the upper range of forest soil solutions.

The nitrate concentrations measured in the soil solutions are the net result from nitrate-producing and consuming processes (e.g. nitrification, denitrification, microbial immobilization, plant uptake) and from mixing with ground and river water. Despite these multiple processes, the large concentrations of nitrate in GRASS and MIXED FOREST were probably mainly due to the higher nitrification rates. Shrestha et al. (2012) showed at the same study site that the GRASS zone and the forest plots with fine-textured soils were hot zones of nitrogen turnover. Under the predominant aerobic conditions, $\mathrm{N}$ mineralization appeared to be limiting for the overall microbial $\mathrm{N}$ turnover, and thus ammonium was generally rapidly nitrified, which resulted in nitrate accumulation in the soil. Based on the results of the present study, differences in nitrate concentrations between the plots are partly explained by the FC $(p \leq 0.03)$, underpinning the importance of soil properties on nitrogen transformation. For example, in GRASS the replicate plots G1 and G2 showed large differences in nitrate concentrations, which clearly could be related to differences in FC (Figs. 4 and 5). Shrestha et al. (2012) showed that the potential for nitrification was high in the three FPZs but that the activity of nitrifiers could be limited by low soil moisture. Lower nitrification rates could therefore explain the lower nitrate concentrations in G2 where the soil was much drier (Fig. 5) than in G1 because of the low FC in this loamy sand (Table 1). However, in most plots with sandy to silty loam, FC and the median VWCs were higher (Fig. 4), leading to higher nitrification rates (Maag and Vinther, 1996). The general accordance of FC and median VWC also indicates that the soil solution in the different FPZs was collected at similar soil matric potentials, suggesting that nitrate concentrations were probably measured in similar water fractions in the different FPZs.

In WILLOW BUSH (WB1 and WB2), nitrate concentrations were very low, even lower than those at G2 (Fig. 4). We assume that the high demand of $\mathrm{N}$ by the still young (7 yr) and rapidly growing Salix viminalis (Rytter, 2001) led to either high nitrate uptake, or competition for ammonium between the plants and microbes, leading to limited substrate availability for the nitrification process. Considering the preference of ammonium over nitrate by these trees (Burger Chakraborty and Sägesser, 2010), the latter is the more likely reason. Similarly, we conclude that the increasing nitrate concentration with depth in MIXED FOREST can be attributed to a maximum plant uptake in the topsoil.

Flooding affects both nitrate concentration and soil moisture significantly (Fig. 5), and it is not completely clear whether mixing with river water and/or denitrification is the main driver for the observed decline in nitrate concentration during inundation. However, due to the short flood durations, the longest in GRASS lasting between 1 and 3 days at G1, we assume that this inundation time is often too short to reach redox potentials sufficiently low to favor denitrification. This assumption is also supported by the study of Pinay et al. (2000) where the flood frequency was too short to observe any significant influence by soil denitrification.

\subsection{Nitrate leaching and $N$ status}

The statistical performance of the CoupModel (Table 3) was similar to that shown by a study of Christiansen et al. (2006) assessing nitrate leaching in temperate Norway spruce and beech forests; the exception was in G2, where we were not able to reflect the dry period from September till mid November 2009 (Fig. 5), leading to an overestimation of the simulated VWC. However, this is of minor concern because water fluxes are mainly driven by VWC differences between FC and saturation, which were well reproduced by the model.

The largest water fluxes were observed in the low-lying plots, i.e. in GRASS and at MF4 in MIXED FOREST, where the sampled soil depths were closer to the aquifer. By contrast, for plots in MIXED FOREST that are located higher, water fluxes were small and mainly driven by precipitation, with little influence from groundwater (Fig. 5). Because the variability of nitrate concentrations between the plots is higher (difference of two orders of magnitude between the plots with the lowest and the highest nitrate concentrations) than the variability of water fluxes, differences in nitrate leaching are mainly driven by variations in nitrate concentration (Fig. 4 and Table 3). Hence, due to the low nitrate concentration, nitrate leaching is minor in WILLOW BUSH compared to GRASS and MIXED FOREST.

The spatial variability in concentrations and leaching of nitrate between the plots within MIXED FOREST and GRASS was substantial. This suggests that the FC of the soil and the depth of the groundwater table might be more important factors than the position in the succession stage. In contrast, both plots within WILLOW BUSH showed consistently low concentrations and fluxes of nitrate, highlighting the role of the vegetation in this zone.

The standard errors of the nitrate fluxes (Table 3), including the temporal variability in nitrate concentrations, might be underestimated during the late autumn and winter, especially in GRASS (G1, G2) and in MF1 and MF2. Large nitrate fluxes were calculated during this period due to high nitrate concentrations and large water fluxes. The sampling of soil solution during this time was more sporadic (monthly) and therefore the temporal variability of nitrate concentrations is rather uncertain. Since the estimated nitrate fluxes during the winter contributed substantially to the annual fluxes, we tested a conservative scenario assuming that nitrate concentrations during the winter were similar to the annual median concentrations. This scenario resulted in winter and annual nitrate fluxes similar to the estimates 
given in Table 3 at all plots, except at MF1 and MF2 where the annual nitrate fluxes would decline to values of 27$30 \mathrm{~kg} \mathrm{Nha}^{-1} \mathrm{yr}^{-1}$. It can be concluded that, despite the uncertainties in nitrate concentrations, the low nitrate fluxes in WILLOW BUSH compared to the leaching in GRASS and MIXED FOREST were likely caused by a high nitrate uptake by the young willows or a limited ammonium availability.

There are no comparable studies on nitrate leaching from riparian soils. Thus, we can only compare our data to studies from forested sites that were performed to predict nitrate leaching based on $\mathrm{N}$ atmospheric deposition and the $\mathrm{N}$ soil status (MacDonald et al., 2002; De Vries et al., 2003; Dise et al., 2009). In MIXED FOREST, with an average of $53 \mathrm{~kg} \mathrm{~N} \mathrm{ha}^{-1} \mathrm{yr}^{-1}$ and a maximum of $94 \mathrm{~kg} \mathrm{Nha}^{-1} \mathrm{yr}^{-1}$, the nitrate leaching losses are very high considering a survey of 181 forest sites with a mean $\mathrm{N}$ export by leaching of $6 \mathrm{~kg} \mathrm{Nha}^{-1} \mathrm{yr}^{-1}$ and a maximum of $43 \mathrm{~kg} \mathrm{Nha}^{-1} \mathrm{yr}^{-1}$ (MacDonald et al., 2002).

Because of the strong nitrate leaching in MIXED FOREST, we assume a nitrogen saturation of the soils, i.e. the availability of mineral $\mathrm{N}$ exceeds the combined nutritional demands of plants and microbes (Aber et al., 1989). Considering the classification of $\mathrm{N}$ saturation for forest soils, which is based on changes in seasonality and levels of nitrate leaching in streams (Stoddard, 1994; Gundersen et al., 2006), the constantly high nitrate concentration with only a weak seasonal pattern at $100 \mathrm{~cm}$ depth (Fig. 5f) supports our assumption.

To test the effect of nitrate leaching below MIXED FOREST on groundwater quality for high water and $\mathrm{N}$ fluxes we used a linear mixing model. Properties of the aquifer used in this model are the following (Vogt et al., 2010a, 2010b): specific discharge $q_{\text {aquifer }}=1$ to $10 \mathrm{~m} \mathrm{~d}^{-1}$, thickness $h=5-6 \mathrm{~m}$, and porosity $\Phi=0.25 \mathrm{~m}^{3} \mathrm{~m}^{-3}$. For the nitrate concentration in groundwater we used $136 \mu \mathrm{moll}^{-1}$ (Peter, 2011). At MF4 at $100 \mathrm{~cm}$ depth, the vertical water flow through the soil during the major flood in July was $931 \mathrm{~m}^{-2}$ over 5 days with an average nitrate concentration of $1028 \mu \mathrm{moll}^{-1}$ (Table 3 and Fig. 5). Based on these figures, the nitrate contribution from soil into groundwater at MF4 ranged between 1 and $11 \%$ of nitrate in the aquifer, depending on aquifer discharge.

\subsection{N balance}

The organic $\mathrm{N}$ input by sedimentation in GRASS and WILLOW BUSH, often exceeding $100 \mathrm{~kg} \mathrm{~N} \mathrm{ha}^{-1} \mathrm{yr}^{-1}$, was in the same range as found for reedbeds $\left(210-240 \mathrm{~kg} \mathrm{~N} \mathrm{ha}^{-1} \mathrm{yr}^{-1}\right.$ ) and for woodlands (43-112 $\mathrm{kg} \mathrm{N} \mathrm{ha}^{-1} \mathrm{yr}^{-1}$ ) along two distributaries of the river Rhine (Olde Venterink et al., 2006). We did not observe significant erosion at any plot. It should be noted that $\mathrm{N}$ sedimentation is controlled by organic matter accumulation and hence is not equal to available $\mathrm{N}$. Because of the linear relationship between $\mathrm{N}$ and organic $\mathrm{C}$ content of deposited sediments $(\mathrm{C} / \mathrm{N}$ ratio of fresh sediments was around 11 in all FPZs, Weibel, 2011), we assume as in earlier studies (Stoeckel and Miller-Goodman, 2001; Noe and Hupp, 2005) that $\mathrm{N}$ is dominantly organic and has first to be mineralized. Furthermore, this low $\mathrm{C} / \mathrm{N}$ ratio compared to that of the top $10 \mathrm{~cm}(\mathrm{C} / \mathrm{N}$ ratio $=15$, Table 1$)$ suggests that around $30 \%$ of the organic matter in the newly deposited sediments is easily degradable.

The minor input of dissolved $\mathrm{N}$ by the Thur River and groundwater into the soil $\left(<8 \mathrm{~kg} \mathrm{Nha}^{-1} \mathrm{yr}^{-1}\right)$ in all plots (Table 4) can be explained by the low dissolved nitrogen concentrations in river and groundwater (Table 2; Peter, 2011) and the short contact times with the soil.

In our study we did not quantify $\mathrm{N}$ loss by denitrification. Reported values vary from $1.1 \mathrm{~kg} \mathrm{Nha}^{-1} \mathrm{yr}^{-1}$ in a sandy loam soil of a well-drained riparian forest (Davis et al., 2011), $6 \mathrm{~kg} \mathrm{~N} \mathrm{ha}^{-1} \mathrm{yr}^{-1}$ for shallow groundwater in loamy sand soil of a riparian forest (Groffman et al., 1996), up to $60 \mathrm{~kg} \mathrm{ha}^{-1} \mathrm{yr}^{-1}$ in a sandy aquifer of a riparian forest (Jordan et al., 1993). Similarly to the high variability in nitrate concentration and of other control factors driving denitrification, there is a high spatiotemporal variability of soil $\mathrm{N}$ effluxes. In GRASS where soils are more frequently flooded and are inundated for a longer time (Table 1 and Fig. 5), N loss can be assumed to be in the upper range of these reported values, whereas in WILLOW BUSH and MIXED FOREST the value might be at the lower end.

There is a positive apparent $\mathrm{N}$ retention in the dynamic FPZs and negative $\mathrm{N}$ retention in the stable MIXED FOREST (Table 4). These findings are similar to the conceptual model of $\mathrm{N}$ dynamics proposed for two fens in the Netherlands by Koerselman et al. (1990). In early successional stages, i.e. GRASS and WILLOW BUSH, the dominant process is $\mathrm{N}$ sedimentation ( $\mathrm{N}$ sink) increasing the buffering capacity of the river corridor (Olde Venterink et al., 2006). With increasing distance from the river, in the mature MIXED FOREST, soils are less hydrologically linked with the river and $\mathrm{N}$ sedimentation is smaller. In soils with low $\mathrm{C} / \mathrm{N}$ ratios, high $\mathrm{FCs}$ and VWCs near FC, high amounts of nitrogen that have been accumulated at earlier successional stages (soil $\mathrm{N}$ pools in Table 4) are mineralized and nitrified. As a consequence, nitrate leaching from the unsaturated zone into groundwater occurs ( $\mathrm{N}$ source), especially at MF4. Even if the nitrate leaching at MF1 and MF2 was lower (27-30 $\mathrm{kg} \mathrm{N} \mathrm{ha}^{-1} \mathrm{yr}^{-1}$ ) than the values presented in Table 3 (see earlier discussion), the decreasing gradient in apparent $\mathrm{N}$ retention from the GRASS zone to the MIXED FOREST would still be apparent. 


\section{Conclusions}

Our findings show that nitrate leaching from shorthydroperiod floodplain soils into groundwater can be substantial. In subsoils with elevetad FCs in GRASS and MIXED FOREST, high nitrate concentrations were measured, often exceeding the Swiss and EU groundwater quality criterion of 400 and $800 \mu \mathrm{moll}^{-1}$, respectively. In these zones, nitrate leaching from the unsaturated zone into groundwater can lead to a significant nitrate contribution during flood events and in winter when soil water fluxes are high.

In contrast, high $\mathrm{N}$ plant uptake by the still young Salix viminalis led to very low nitrate concentrations and fluxes in WILLOW BUSH. However, N retention by willow trees decreases with age and nitrate leaching might increase again. Regular harvesting could be an effective practice to remove $\mathrm{N}$ permanently from the system.

Highest $\mathrm{N}$ retention rates were observed in the dynamic FPZs (GRASS and WILLOW BUSH), increasing the self cleaning-capacity of the river. By contrast, in the stable MIXED FOREST, nitrate leaching exceeded total $\mathrm{N}$ input most of the time. As a result of large soil $\mathrm{N}$ pools that have accumulated during the entire successional development, high amounts of nitrate are produced by nitrification but cannot be retained by the $\mathrm{N}$ saturated forest soil.

Acknowledgements. This research was supported by COST Action FP0601 and the ETH Competence Centre of Environment and Sustainability (CCES). We gratefully thank the team members of the RECORD project for valuable collaboration, in particular Tobias Vogt for the piezometer data, Nicola Pasquale for the inundation maps and Emanuela Samaritani for the support in the field and laboratory. We also thank the technicians from the WSL units Forest Soils and Biogeochemistry, and Central Laboratory.

Edited by: J. Kesselmeier

\section{References}

Aber, J. D., Nadelhoffer, K. J., Steudler, P., and Melillo, J. M.: Nitrogen saturation in northern forest ecosystems, Bioscience, 39, 378-386, doi:10.2307/1311067, 1989.

Baldwin, D. S. and Mitchell, A. M.: The effects of drying and re-flooding on the sediment and soil nutrient dynamics of lowland river-floodplain systems: A synthesis, Regul. River, 16, 457-467, doi:10.1002/1099-1646(200009/10)16:5;457::AIDRRR597i3.0.CO;2-b, 2000.

Burger Chakraborthy, L. and Sägesser, J.: Nitrate and ammonium uptake by two riparian plant species, B. Sc. Thesis, D-UWIS, ETH Zurich, 35 pp., 2010.

Christiansen, J. R., Elberling, B., and Jansson, P. E.: Modelling water balance and nitrate leaching in temperate Norway spruce and beech forests located on the same soil type with the CoupModel, Forest Ecol. Manag., 237, 545-556, doi:10.1016/j.foreco.2006.09.090, 2006.
Davis, J. H., Griffith, S. M., and Wigington, P. J.: Surface water and groundwater nitrogen nynamics in a well drained riparian forest within a poorly drained agricultural landscape, J. Environ. Qual., 40, 505-516, doi:10.2134/jeq2010.0310, 2011.

De Vries, W., Reinds, G. J., van der Salm, C., Draaijers, G. P. J., Bleeker, A., and Erisman, J. W.: Intensive monitoring of forest ecosystems in Europe, EC, UN/ECE, Brussels, Geneva, 177 pp., 2001.

De Vries, W., Reinds, G. J., and Vel, E.: Intensive monitoring of forest ecosystems in Europe 2: Atmospheric deposition and its impacts on soil solution chemistry, Forest Ecol. Manag., 174, 97 115, doi:10.1016/s0378-1127(02)00030-0, 2003.

Dise, N. B., Rothwell, J. J., Gauci, V., van der Salm, C., and de Vries, W.: Predicting dissolved inorganic nitrogen leaching in European forests using two independent databases, Sci. Total Environ., 407, 1798-1808, doi:10.1016/j.scitotenv.2008.11.003, 2009.

FOEN: Discharge data from Federal Office for the Environment, http://www.hydrodaten.admin.ch/de/2044.html, last access: 6 November 2011.

Gee, G. W. and Brauder, J. W.: Particle-size analysis, in: Methods of Soil Analysis. Part I. Agron. Monogr. 9, edited by: Klute, A., ASA and SSSA, Madison, Madison, WI, 383-411, 1986.

Groffman, P. M., Howard, G., Gold, A. J., and Nelson, W. M.: Microbial nitrate processing in shallow groundwater in a riparian forest, J. Environ. Qual., 25, 1309-1316, 1996.

Gundersen, P., Schmidt, I. K., and Raulund-Rasmussen, K.: Leaching of nitrate from temperate forests - effects of air pollution and forest management, Environ. Rev., 14, 1-57, doi:10.1139/a05015, 2006.

Hefting, M., Clement, J. C., Dowrick, D., Cosandey, A. C., Bernal, S., Cimpian, C., Tatur, A., Burt, T. P., and Pinay, G.: Water table elevation controls on soil nitrogen cycling in riparian wetlands along a European climatic gradient, Biogeochemistry, 67, 113134, doi:10.1023/b:biog.0000015320.69868.33, 2004.

Hefting, M., Beltman, B., Karssenberg, D., Rebel, K., van Riessen, M., and Spijker, M.: Water quality dynamics and hydrology in nitrate loaded riparian zones in the Netherlands, Environ. Pollut., 139, 143-156, doi:10.1016/j.envpol.2005.04.023, 2006.

Howard-Williams, C.: Cycling and retention of nitrogen and phosphorus in wetlands - A theoretical and applied perspective, Freshwater Biol., 15, 391-431, doi:10.1111/j.13652427.1985.tb00212.x, 1985.

IUSS Working Group WRB: World reference base for soil resources, 2nd edition: World Soil Resources Reports No 103, FAO, Rome, 132 pp., 2006.

Jansson, P. E. and Karlberg, L.: Coupled heat and mass transfer model for soil-plant-atmosphere systems, Stockholm: Royal Institute of Technology, Dept of Civil and Environmental Engineering, http://www2.lwr.kth.se/Vara\%20Datorprogram/ CoupModel/coupmanual.pdf, 2004.

Jordan, T. E., Correll, D. L., and Weller, D. E.: Nutrient interception by a riparian forest receiving inputs from adjacent cropland, J. Environ. Qual., 22, 467-473, 1993.

KA5: Bodenkundliche Kartieranleitung, 5, verbesserte und erweiterte Auflage Bundesanstalt für Geowissenschaften und Rohstoffe in Zusammenarbeit mit den Staatlichen Geologischen Diensten der Bundesrepublik Deutschland, 438 pp., 2005. 
Koerselman, W., Bakker, S. A., and Blom, M.: Nitrogen, phosphorus and potassium budgets for 2 small fens surrounded by heavily fertilized pastures, J. Ecol., 78, 428-442, doi:10.2307/2261122, 1990.

Maag, M. and Vinther, F. P.: Nitrous oxide emission by nitrification and denitrification in different soil types and at different soil moisture contents and temperatures, Appl. Soil Ecol., 4, 5-14, 1996.

MacDonald, J. A., Dise, N. B., Matzner, E., Armbruster, M., Gundersen, P., and Forsius, M.: Nitrogen input together with ecosystem nitrogen enrichment predict nitrate leaching from European forests, Glob. Change Biol., 8, 1028-1033, doi:10.1046/j.13652486.2002.00532.x, 2002.

Mayer, P. M., Reynolds, S. K., McCutchen, M. D., and Canfield, T. J.: Meta-analysis of nitrogen removal in riparian buffers, J. Environ. Qual., 36, 1172-1180, doi:10.2134/jeq2006.0462, 2007.

Nanson, G. C. and Croke, J. C.: A genetic classification of floodplains, Geomorphology, 4, 459-486, doi:10.1016/0169555x(92)90039-q, 1992.

Noe, G. B. and Hupp, C. R.: Carbon, nitrogen, and phosphorus accumulation in floodplains of Atlantic Coastal Plain rivers, USA, Ecol. Appl., 15, 1178-1190, doi:10.1890/04-1677, 2005.

Noe, G. B. and Hupp, C. R.: Seasonal variation in nutrient retention during inundation of a short-hydroperiod floodplain, River Res. Appl., 23, 1088-1101, doi:10.1002/rra.1035, 2007.

Olde Venterink, H., Vermaat, J. E., Pronk, M., Wiegman, F., van der Lee, G. E. M., van den Hoorn, M. W., Higler, L., and Verhoeven, J. T. A.: Importance of sediment deposition and denitrification for nutrient retention in floodplain wetlands, Appl. Veg. Sci., 9, 163-174, 2006.

Pasquale, N., Perona, P., Schneider, P., Shrestha, J., Wombacher, A., and Burlando, P.: Modern comprehensive approach to monitor the morphodynamic evolution of a restored river corridor, Hydrol. Earth Syst. Sci., 15, 1197-1212, doi:10.5194/hess-151197-2011, 2011.

Peter, S.: Spatial and temporal variability in the transport and transformation of organic matter and nitrogen in a restored riparian aquifer, PhD. Thesis, ETH/EAWAG, doi:10.3929/ethz-a007317813, 2011.

Pinay, G., Ruffinoni, C., and Fabre, A.: Nitrogen cycling in 2 riparian forest soils under different geomorphic conditions, Biogeochemistry, 30, 9-29, doi:10.1007/bf02181038, 1995.

Pinay, G., Black, V. J., Planty-Tabacchi, A. M., Gumiero, B., and Decamps, H.: Geomorphic control of denitrification in large river floodplain soils, Biogeochemistry, 50, 163-182, doi:10.1023/a:1006317004639, 2000.

Pinay, G., Clement, J. C., and Naiman, R. J.: Basic principles and ecological consequences of changing water regimes on nitrogen cycling in fluvial systems, Environ. Manag., 30, 481-491, doi:10.1007/s00267-002-2736-1, 2002.

Powlson, D. S., Addisott, T. M., Benjamin, N., Cassman, K. G., de Kok, T. M., van Grinsven, H., L'Hirondel, J. L., Avery, A. A., and van Kessel, C.: When does nitrate become a risk for humans?, J. Environ. Qual., 37, 291-295, doi:10.2134/jeq2007.0177, 2008.

Rytter, R. M.: Biomass production and allocation, including fineroot turnover, and annual $\mathrm{N}$ uptake in lysimeter-grown basket willows, Forest Ecol. Manag., 140, 177-192, 2001.

Samaritani, E., Shrestha, J., Fournier, B., Frossard, E., Gillet, F., Guenat, C., Niklaus, P. A., Pasquale, N., Tockner, K., Mitchell,
E. A. D., and Luster, J.: Heterogeneity of soil carbon pools and fluxes in a channelized and a restored floodplain section (Thur River, Switzerland), Hydrol. Earth Syst. Sci., 15, 1757-1769, doi:10.5194/hess-15-1757-2011, 2011.

Shrestha, J., Niklaus, P. A., Frossard, E., Samaritani, E., Huber, B., Barnard, R. L., Schleppi, P., Tockner, K., and Luster, J.: Soil nitrogen dynamics in a river floodplain mosaic, J. Environ. Qual., 41, 2033-2045, doi:10.2134/jeq2012.0059, 2012.

Schneider, P., Vogt, T., Schirmer, M., Doetsch, J., Linde, N., Pasquale, N., Perona, P., and Cirpka, O. A.: Towards improved instrumentation for assessing river-groundwater interactions in a restored river corridor, Hydrol. Earth Syst. Sci., 15, 2531-2549, doi:10.5194/hess-15-2531-2011, 2011.

Steiger, J., Gurnell, A. M., and Goodson, J. M.: Quantifying and characterizing contemporary riparian sedimentation, River Res. Appl., 19, 335-352, doi:10.1002/rra.708, 2003.

Stoddard, J. L.: Long-term changes in watershed retention of nitrogen - its causes and aquatic consequences, in: Environmental Chemistry of Lakes and Reservoirs, edited by: Baker, L. A., Adv. Chem. Ser., 223-284, 1994.

Stoeckel, D. M. and Miller-Goodman, M. S.: Seasonal nutrient dynamics of forested floodplain soil influenced by microtopography and depth, Soil Sci. Soc. Am. J., 65, 922-931, 2001.

R Development Core Team: R: A language and Environment for Statistical Computing. The R Foundation for Statistical Computing, Vienna, available at http://www.R-project.org/, 2011.

Teepe, R., Dilling, H., and Beese, F.: Estimating water retention curves of forest soils from soil texture and bulk density, J. Plant Nutr. Soil Sc., Zeitschrift Für Pflanzenernährung und Bodenkunde, 166, 111-119, doi:10.1002/jpln.200390001, 2003.

Thimonier, A.: Measurement of atmospheric deposition under forest canopies: Some recommendations for equipment and sampling design, Environ. Monit. Assess., 52, 353-387, doi:10.1023/a:1005853429853, 1998.

Thimonier, A., Schmitt, M., Waldner, P., and Rihm, B.: Atmospheric deposition on Swiss long-term forest ecosystem research (LWF) plots, Environ. Monit. Asses., 104, 81-118, doi:10.1007/s10661-005-1605-9, 2005.

Thorp, J. H., Thoms, M. C., and Delong, M. D.: The riverine ecosystem synthesis: Biocomplexity in river networks across space and time, River Res. Appl., 22, 123-147, doi:10.1002/rra.901, 2006.

Tockner, K. and Stanford, J. A.: Riverine flood plains: Present state and future trends, Environ. Conserv., 29, 308-330, doi:10.1017/s037689290200022x, 2002.

Ulrich, B.: Interaction of forest canopies with atmospheric constituents: $\mathrm{SO}_{2}$, alkali and earth alkali cations and chloride, in: Effects of accumulation of air pollutants in forest ecosystems, edited by: Ulrich, B. and Pankrath, J., Reidel, Dordrecht, 33-45, 1983.

Vitousek, P. M., Aber, J. D., Howarth, R. W., Likens, G. E., Matson, P. A., Schindler, D. W., Schlesinger, W. H., and Tilman, G. D.: Human alteration of the global nitrogen cycle: Sources and consequences, Ecol. Appl., 7, 737-750, 1997.

Vogt, T., Hoehn, E., Schneider, P., Freund, A., Schirmer, M., and Cirpka, O. A.: Fluctuations of electrical conductivity as a natural tracer for bank filtration in a losing stream, Adv. Water Resour., 33, 1296-1308, doi:10.1016/j.advwatres.2010.02.007, 2010a.

Vogt, T., Schneider, P., Hahn-Woernle, L., and Cirpka, O. A.: Estimation of seepage rates in a losing stream by means of fiber- 
optic high-resolution vertical temperature profiling, J. Hydrol., 380, 154-164, doi:10.1016/j.jhydrol.2009.10.033, 2010b.

Walthert, L., Graf, U., Kammer, A., Luster, J., Pezzotta, D., Zimmermann, S., and Hagedorn, F.: Determination of organic and inorganic carbon, $\delta^{13} \mathrm{C}$, and nitrogen in soils containing carbonates after acid fumigation with HCI, J. Plant Nutri. Soil Sci., 173, 207-216, doi:10.1002/jpln.200900158, 2010.
Weibel, R.: Nitrogen deposition in a riparian zone, B.Sc. Swiss Federal Institute of Technology (ETH), Swiss Federal Institute for Forest, Snow and Landscape Research (WSL), doi:10.3929/ethza-006995384, 2011. 